\title{
Vegetation response of a mesquite-mixed brush community to aeration
}

\author{
DONALD C. RUTHVEN III AND KEITH L. KRAKAUER
}

Authors are Natural Resource Specialist, Chaparral Wildlife Management Area, Texas Parks and Wildlife Department, Artesia Wells, Tex. 78001, and Graduate Research Assistant, Texas A\&M University-Kingsville, Kingsville, Tex. 78363.

\author{
Abstract
}

Responses of plant communities to mechanical treatments such as aeration on semiarid rangelands are not clearly understood. Our objective was to compare woody and herbaceous plant cover, density, and diversity on aerated and nontreated rangelands. Five rangeland sites that were aerated with a double/tandem drum aerator during summer 1998 and 5 sites of nontreated rangeland were selected for study on the Chaparral Wildlife Management Area, La Salle County, Tex. Woody plant cover was estimated using the line-intercept method, and stem density was estimated in $30 \times 1.5 \mathrm{~m}$ plots in 1999 and 2000 . Forb and grass cover and density were estimated in $20 \times 50 \mathrm{~cm}$ quadrats during spring and fall 1999. Woody and herbaceous plant diversity did not differ between treatments. On aerated sites percent woody plant cover was 4-fold less 1-year after aeration and increased $89 \%$ from the first to the second growing-season post treatment. Canopy cover of honey mesquite (Prosopis glandulosa Torr.), twisted acacia (Acacia schaffneri S. Wats.), and Texas pricklypear (Opuntia lindheimeri Engelm.) was greater on nontreated sites. By the second growing season after aeration, density of honey mesquite was greater on aerated sites, whereas Texas pricklypear had declined on aerated sites. Density of spiny hackberry (Celtis pallida Torr.) and Texas persimmon (Diospyros texana Scheele) was greater on aerated sites during the first growing-season post treatment. Cover and stem density of hog-plum (Colubrina texana T. \& G.), coma (Bumelia celastrina Kunth), and whitebrush [Aloysia gratissima (Gill. \& Hook.) Tron.] did not differ among aerated and nontreated sites by the first growing season after aeration. Forb cover was greater on aerated sites in spring 1999. Fringed signalgrass [Brachiaria ciliatissima (Buckl.) Chase], fall witchgrass [Digitaria cognata (Schult.) Pilger], and bristlegrass (Setaria spp. Beauv.) cover was greater on aerated sites in spring and fall 1999, whereas purple threeawn (Aristida purpurea Nutt.) was greater on nontreated sites. It is unclear to what degree environmental factors such as pre- and post-treatment climatic conditions and herbivory may have influenced vegetation response to aeration. The rapid regrowth of many woody plants following aeration may require the application of maintenance treatments within a relatively short time period to maintain treatment benefits. Aeration reduced total woody plant cover, increased the density of desirable woody plants, maintained woody plant diversity, increased grass cover, and may be a useful tool in managing South Texas rangelands for whitetailed deer (Odocoileus virginianus Boddaert) and cattle.

The authors thank David Rios, Adan Gandaria, and Randy Rosales for assistance with data collection, Jim Gallagher for assistance with statistical analyses, and Jesús Franco for translation of the Spanish abstract. Research funding was provided by the Texas Parks and Wildlife Department.

Manuscript accepted 6 Jun. 03.

\section{Resúmen}

La respuesta de las comunidades vegetales de pastizales semidesérticos a tratamientos mecánicos tales como la aereación no ha sido claramente entendida. Nuestro objetivo fué comparar la cobertura, densidad y diversidad de especies leñosas y herbáceas, en pastizales tratados con aereación y en pastizales no tratados. Diez sitios de estudio fueron seleccionados en el Area de Manejo de Fauna Silvestre Chaparral, en el condado La Salle, en Texas. Durante el verano de 1998, cinco sitios recibieron tratamiento de aereación por medio de un implemento de doble tambor ó rodillo; los otros cinco sitios no recibieron tratamiento. En 1999 y en el 2000, se estimó la cobertura de plantas leñosas por medio del método de intercepción de linea, mientras que la densidad de tocones se estimó en cuadrantes de 25 x $1.5 \mathrm{~m}$. Durante la primavera y el otoño de 1999, se estimó la cobertura y densidad de plantas herbáceas y arbustivas, utilizando cuadrantes de $20 \times 50$ $\mathrm{cm}$. La densidad de plantas leñosas y herbáceas no fué diferente entre tratamientos. Un año después de la aplicación del tratamiento, el porcentaje de cobertura de plantas leñosas fué 4 veces menor en los sitios tratados, pero ésta se incrementó en un $89 \%$, de la primera a la segunda estación de crecimiento después de la aereación. La cobertura de Prosopis glandulosa Torr., Acacia schaffneri S. Wats.y Opuntia lindheimeri Engelm. fué mayor en sitios no tratados. Para la segunda estación de crecimiento, la densidad de Prosopis glandulosa Torr. fué mayor en sitios aereados, mientras que la densidad de Opuntia lindheimeri Engelm. declinó. Durante la primera estación de crecimiento, la densidad de Celtis pallida Torr. y Diospyros texana Scheele fué mayor en los sitios tratados. Durante la primera estación de crecimiento la cobertura y densidad de tocones de Colubrina texana T. \& G., Bumelia celastrina Kunth, y Aloysia gratissima (Gill. \& Hook.) Tron. permaneció igual en sitios tratados y no tratados. Durante la primavera de 1999, la cobertura de herbáceas fué mayor en sitios tratados. Durante la primavera y otoño de 1999 la cobertura de Brachiaria ciliatissima (Buckl.) Chase, Digitaria cognata (Schult.) Pilger y Setaria spp. Beauv. fué mayor en los sitios tratados, mientras que la cobertura de Aristida purpurea Nutt. fué mayor en sitios no tratados. El grado de influencia de algunos factores ambientales -como las condiciones climáticas antes y después del tratamiento, y los herbívoros-, sobre la respuesta de la vegetación al tratamiento permanence poco claro. Debido al rápido rebrote de muchas especies leñosas después de la aereación, tal vez sea necesario aplicar tratamientos de mantenimiento adicionales a corto plazo para manterner los beneficios del tratamiento. El tratamiento de aereación redujo la cobertura total de plantas leñosas, incrementó la densidad de plantas leñosas deseables, mantuvo la densidad de plantas leñosas, e incrementó la cobertura de plantas herbáceas. Es probable que éste tratamiento sea una buena herramienta de manejo para los 
pastizales del sur de Texas dedicados a la ganadería y al venado de cola blanca (Odocoileus virginianus Boddaert).

Key Words: diversity, herbaceous vegetation, South Texas, range improvement, wildlife habitat, woody vegetation

Suppression of fire combined with heavy livestock grazing has lead to the conversion of the South Texas Plains from a grassland/savanna to a thorn woodland (Archer et al. 1988, Archer 1994). With the development of heavy machinery in the mid-twentieth century, South Texas landowners began to convert these thorn woodlands back to grasslands to benefit livestock production. Mechanical treatments effectively manage woody vegetation and enhance herbaceous vegetation (Scifres et al. 1976, Bozzo et al. 1992a). Total plant removal methods such as root plowing are the most effective in managing woody plants (Allison and Rechenthin 1956) and have an extended treatment life (Welch et al. 1985). However, once root plowed rangelands are revegetated by woody species, woody plant diversity can be dramatically reduced (Fulbright and Beasom 1987, Ruthven et al. 1993). Mechanical top removal methods such as chaining (Scifres et al. 1976) and roller chopping (Fulbright and Beasom 1987) are less destructive of woody plant diversity than root plowing, but treatment life is generally short (Welch et al. 1985).

Land ownership and land use practices in South Texas have changed in recent years. The size of individual landholdings has decreased and revenue derived from those properties has become increasingly dependent on consumptive and non-consumptive wildlife enterprises rather than traditional livestock operations (Wilkins et al. 2000). In South Texas, woody vegetation is a primary component of whitetailed deer (Odocoileus virginianus Boddaert) diet (Arnold and Drawe 1979, Taylor et al. 1997). Mechanical top removal methods have been shown to increase crude protein, phosphorous, and potassium content of browse species preferred by white-tailed deer (Everitt 1983, Fulbright et al. 1991). Woody plants are also an important cover source for northern bobwhite (Colinus virginianus L.) (Guthrey 1986), and provide escape cover and thermal refugia to species of concern such as Texas tortoise (Gopherus berlandieri Stejneger) (Kazmaier 2000) and Texas horned lizard (Phrynosoma cornutum Gray) (Burrow et al. 2001).

Because of its purported destruction of woody plant canopies and improvement of air and water movement through fracturing of surface soil layers, aeration is rapidly becoming the preferred choice of wildlife mangers to manage vegetation in South Texas (Personal Comm., J. Burnside 1998). Aerators differ from roller choppers in that the blades along the chopper drum are toothed and set at an angle across the face of the drum rather than a continuous blade running parallel to the face of the drum. Aerators are commonly used to renovate improved pastures in the southeastern United States. Few data however, are available on the effects of aeration on vegetation of semiarid rangelands. Our objective was to determine the effects of aeration on the composition of woody and herbaceous plant communities in the western South Texas Plains. We hypothesized that aeration would maintain woody plant diversity, increase woody plant stem density, and increase herbaceous vegetation compared to nontreated sites.

\section{Materials and Methods}

The study area was on the Chaparral Wildlife Management Area $\left(28^{\circ} 20^{\prime} \mathrm{N}\right.$, $99^{\circ} 25^{\prime} \mathrm{W}$ ) in the western South Texas Plains. The study site was purchased by the state of Texas in 1969, and is managed by the Wildlife Division of the Texas Parks and Wildlife Department (TPWD). Climate is characterized by hot summers and mild winters with an average daily minimum January temperature of $5^{\circ} \mathrm{C}$, an average daily maximum July temperature of $37^{\circ} \mathrm{C}$, and a growing season of 249 to 365 days depending on the occurrence of freezing temperatures (Stevens and Arriaga 1985). Precipitation pattern is bimodal with peaks occurring in late spring (May-June) and early fall (September-October). The 12-year (1989-2000) average precipitation is 54 $\mathrm{cm}$ (Unpublished data, TPWD).

Five study plots were aerated with 1 pass during August 1998 using a double/tandem $4.4 \times 0.8 \mathrm{~m}$ drum aerator (Lawson Manufacturing Inc., Kissimmee, Fla.) pulled by a D7 bulldozer. Study plots were about $400 \times 70 \mathrm{~m}$ in size. Randomly selected nontreated areas of similar size and shape adjacent and parallel to treated plots served as control plots. Study plot pairs were interspersed among 2 pastures in the southeastern portion of the study area and each pair separated by $>700 \mathrm{~m}$. Although pretreatment sampling was not conducted, total woody plant canopy cover and composition of dominant woody species was considered similar among study plots before application of aeration treatments based on previous vegetation sampling (Gabor 1997, Unpublished data, TPWD).

Soils were similar among treatments and consisted of Duval fine sandy loam on gently undulating slopes, Duval loamy fine sand on $0-5 \%$ slopes, and Dilley fine sandy loam on gently undulating slopes (Stevens and Arriaga 1985, Gabriel et al. 1994). The Duval series are fine-loamy, mixed, hyperthermic Aridic Haplustalfs and the Dilley series are loamy, mixed, hyperthermic shallow Ustalfic Haplargids. Topography is nearly level to gently sloping and elevation ranges between 152 and $177 \mathrm{~m}$ above sea level.

Vegetation is characterized by a 2-phase pattern of shrub clusters scattered throughout a savanna (Whittaker et al. 1979, Archer et al. 1988). Plant communities belong to the honey mesquite (Prosopis glandulosa Torr.) - spiny hackberry (Celtis pallida Torr.) association (McLendon 1991). Within this association were 2 primary communities; the honey mesquite lime pricklyash [Zanthoxylum fagara (L.) Sarg.]/spiny hackberry community, with lime pricklyash and brasil (Condalia hookeri M. C. Johnst.) the subdominants, and the honey mesquite-spiny hackberry/hogplum (Colubrina texana T. \& G.) community, with hog-plum the subdominant. Prominent herbaceous species included Lehmann lovegrass (Eragrostis lehmanniana Nees), an introduced perennial, hooded windmillgrass (Chloris cucullata Bisch.), hairy grama (Bouteloua hirsuta Lag.), partridge pea [Chamaecrista fasciculata (Michx.) Greene], and croton (Croton spp. L.).

Domestic livestock have grazed the study area since the 18 th century (Lehmann 1969). Cattle have been the major species of livestock since about 1870 , whereas sheep were grazed from about 1750 to 1870 . Grazing strategies have varied from continuous grazing to various rotational grazing systems (Ruthven et al. 2000a). Since 1990 the study area has been grazed by stocker class steers under a high intensity, low frequency grazing system during the period October through April. During the period of this study, research plots were grazed from mid-March through April 1999 and 2000 at 23 animal-unit days ha ${ }^{-1}$ year $^{-1}$. To determine if cattle utilized aerated plots more than adjacent nontreated areas, three, $30 \times 1.5 \mathrm{~m}$ plots were randomly located in each study plot. Plots were monitored in spring 1999 following grazing by counting cattle fecal groups in each plot.

On each plot percent canopy cover of woody, succulent, and suffrutescent plants 
was estimated during summer 1999 and 2000 by the line-intercept method along twenty-five, $30 \mathrm{~m}$ lines (Canfield 1941). Lines were placed at random points along a 300-m transect which was placed through the center of each study plot. Lines were oriented perpendicular to the 300-m transect and the direction of each line randomly chosen.

Vertical cover was visually estimated on a $2.5 \times 0.15 \mathrm{~m}$ profile board (Nudds 1977). The $15 \mathrm{~cm}$ wide profile board was divided into 5 strata, each being $0.5 \mathrm{~m}$ in length. Profile boards were placed at the $15 \mathrm{~m}$ point on each line. Percent visual obstruction, utilizing a ranking system (Nudds 1977), was estimated for each $0.5 \mathrm{~m}$ increment by an observer standing at the $0 \mathrm{~m}$ point of each line. Rankings were converted into percent cover by utilizing the midpoint of each cover class.

Woody, succulent, and suffrutescent plant density and frequency of occurrence were estimated by counting individual plants in a $30 \times 1.5 \mathrm{~m}$ quadrat placed along each of the 25 lines per site in summer 1999 and 2000 . Woody plant species diversity ( $\left.\mathrm{H}^{\prime}\right)$ and evenness ( $\left.\mathrm{J}^{\prime}\right)$ were quantified using Shannon's index (Pielou 1975) using density data to calculate the index.

Herbaceous canopy cover was visually estimated during spring 1999 (MarchApril) and fall 1999 (September-October) in $20 \times 50 \mathrm{~cm}$ quadrats (Daubenmire 1959). Quadrats were randomly placed at $10 \mathrm{~m}$ intervals along three, $330 \mathrm{~m}$ transects which were uniformly distributed on each study plot resulting in a total of 99 quadrats per site. Herbaceous plant density and frequency were estimated by counting individual plants in each quadrat. Density data were used to calculate Shannon's index.

An analysis of variance (ANOVA) for a randomized block design with study plots as experimental units was used to test for treatment effects on vegetation. Each sampling year was analyzed separately. Cattle fecal groups were also evaluated with an ANOVA at the study plot level. Vernacular names and scientific nomenclature of plants follow Hatch et al. (1990).

\section{Results and Discussion}

\section{Response of Woody, Succulent, and Suffrutescent Plants}

Species richness and Shannon's index of diversity and evenness of woody plants were similar among treatments (Table 1). Percent total woody plant cover was greater $\left(\mathrm{P}=0.0010, \mathrm{~F}_{1,8}=25.46\right)$ on nontreated $[39 \pm 6 \%(\bar{x} \pm \mathrm{SE})]$ than aerated $(9$

Table 1. Mean woody plant richness, diversity, and evenness on aerated $(n=5)$ and nontreated $(n=$ 5) sites, La Salle County, Tex. in 1999 and 2000.

\begin{tabular}{lccccc}
\hline \hline & \multicolumn{2}{c}{1999} & & \multicolumn{2}{c}{2000} \\
\cline { 2 - 3 } \cline { 5 - 6 } & Aerated & Nontreated & & Aerated & Nontreated \\
\hline Richness & $17 \mathrm{a}$ & $17 \mathrm{a}$ & & $16 \mathrm{a}$ & $17 \mathrm{a}$ \\
Diversity & $2.19 \mathrm{a}$ & $2.31 \mathrm{a}$ & & $2.19 \mathrm{a}$ & $2.27 \mathrm{a}$ \\
Evenness & $0.78 \mathrm{a}$ & $0.81 \mathrm{a}$ & & $0.79 \mathrm{a}$ & $0.81 \mathrm{a}$ \\
\hline
\end{tabular}

Means within a row and year followed by the same letter are not significantly different $(P>0.05)$.

$\pm 1 \%)$ sites in 1999 and $2000(42 \pm 9 \%$ and $17 \pm 3 \%$, respectively; $\mathrm{P}=0.0274, \mathrm{~F}_{1,8}=$ $7.25)$. Vertical cover was greater on nontreated sites at all profile board strata in 1999 and 2000 (Table 2). Total woody plant density was greater $\left(\mathrm{P}=0.0107, \mathrm{~F}_{1,8}=\right.$ $10.97)$ on aerated $\left(4,028 \pm 297\right.$ stems ha $\left.^{-1}\right)$ than nontreated $(2,831 \pm 206)$ sites in 1999 and $2000(3,937 \pm 452$ and $2,737 \pm 285$, respectively; $\mathrm{P}=0.0549, \mathrm{~F}_{1,8}=5.05$ ).

Aeration appears to be effective in reducing woody plant cover while maintaining woody plant diversity. Although woody plant cover was reduced by the aeration treatment, woody plants increased rapidly as total woody cover increased $89 \%$ and vertical cover at $0.5-1.0 \mathrm{~m}$ was 3-fold greater on aerated sites in 2000 as compared to 1999 . Honey mesquite and twisted acacia (Acacia schaffneri S. Wats.), which can dominate mechanically treated sites in the western South Texas Plains (Fulbright and Beasom 1987), increased in cover by $250 \%$ and $110 \%$, respectively on aerated sites during the course of this study (Table 3 ).

Honey mesquite is the dominant woody plant on most rangelands in South Texas and its management is a primary concern of rangeland managers throughout its range. While honey mesquite canopy cover on aerated sites was 6-times less than on nontreated sites 2 years post treatment (Table 3 ), stem density was $63 \%$ greater on aerated sites (Table 4). Honey mesquite can quickly replace top growth and increase stem density during the first growing season following top-removal treatments (Welch et al. 1985, Scifres and Hamilton 1993). The lack of sprouting by honey mesquite during the first growing season after aeration may be explained by environmental conditions prior to the aeration treatment. Rainfall during the 3 months prior to the aeration treatment ( 1.5 $\mathrm{cm}$ ) was more than 10-times below normal. Although honey mesquite is well adapted to withstand seasonal drought through enhanced physiological activity following drought (Reynolds et al. 1999), removal of photosynthetic material during short-term drought may reduce the ability of honey mesquite to compensate for drought effects. Aeration or other top removal treatments during periods of stress such as drought may increase treatment life; however, further study into the interactions between mechanical treatments and environmental stress factors are needed.

Management of pricklypear (Opuntia spp. Mill.) can also be a concern of livestock and wildlife managers. While Texas pricklypear (Opuntia lindheimeri Engelm.) and other cacti are an important food source for species such as whitetailed deer (Arnold and Drawe 1979) and javelina (Tayassu tajacu L.) (Sowls 1997) in South Texas, large colonies of Texas pricklypear can result in extensive areas virtually devoid of herbaceous vegetation. Pricklypear increases following most mechanical treatments (Box and Powell 1965, Dodd 1968, Montemayor et al. 1991). Tissue destruction associated with vegetation management practices such as prescribed burning increases vulnerability of pricklypear to damage from insects, rodents, and lagomorphs, which can result in high mortality 2-3 years following treatment (Bunting et al. 1980). Reductions of Texas pricklypear cover (Table 3) and density (Table 4) on aerated

Table 2. Mean vertical cover $(\%)$ on aerated $(n=5)$ and nontreated $(n=5)$ sites, La Salle County, Tex., in 1999 and 2000.

\begin{tabular}{|c|c|c|c|c|}
\hline \multirow[b]{2}{*}{ Strata } & \multicolumn{2}{|c|}{1999} & \multicolumn{2}{|c|}{2000} \\
\hline & Aerated & Nontreated & Aerated & Nontreated \\
\hline & \multicolumn{2}{|c|}{-.1\%) $(\%)-\ldots$} & \multicolumn{2}{|c|}{--n- $(\%)$} \\
\hline $0.0-0.5 \mathrm{~m}$ & 29 a & $70 \mathrm{~b}$ & 44 a & $68 \mathrm{~b}$ \\
\hline $0.5-1.0$ & $6 a$ & $60 b$ & $17 \mathrm{a}$ & $60 b$ \\
\hline $1.0-1.5 \mathrm{~m}$ & $3 \mathrm{a}$ & $52 \mathrm{~b}$ & $7 \mathrm{a}$ & $55 \mathrm{~b}$ \\
\hline $1.5-2.0 \mathrm{~m}$ & $3 \mathrm{a}$ & $46 \mathrm{~b}$ & $4 \mathrm{a}$ & $51 \mathrm{~b}$ \\
\hline $2.0-2.5 \mathrm{~m}$ & $2 a$ & $40 \mathrm{~b}$ & $2 \mathrm{a}$ & $44 b$ \\
\hline
\end{tabular}

Means within a row and year followed by a different letter are significantly different $(\mathrm{P}<0.0 \mathrm{I})$. 
Table 3. Mean canopy cover $(\%)$ of dominant (frequency $>25 \%$ ) woody, succulent, and suffrutescent plants on aerated $(n=5)$ and nontreated $(n=5)$ sites, La Salle County, Tex. in 1999 and 2000.

\begin{tabular}{|c|c|c|c|c|}
\hline \multirow[b]{2}{*}{ Class/species } & \multicolumn{2}{|c|}{1999} & \multicolumn{2}{|c|}{2000} \\
\hline & Aerated & Nontreated & Aerated & Nontreated \\
\hline & \multicolumn{2}{|c|}{ - } & \multicolumn{2}{|c|}{--------(\%)--------- } \\
\hline Woody & & & & \\
\hline Brasil & $0.3^{* *}$ & $3.5^{* *}$ & $0.5^{* *}$ & $3.2 * *$ \\
\hline Catclaw acacia & 0.6 & 2.0 & 1.0 & 2.0 \\
\hline Coma & 0.3 & 0.4 & 0.6 & 1.0 \\
\hline Guayacan & 0.1 & 0.5 & 0.4 & 0.9 \\
\hline Hog-plum & 2.2 & 4.0 & 3.9 & 3.1 \\
\hline Honey mesquite & $1.0^{*}$ & $11.2 *$ & $2.1^{\#}$ & $12.7^{\#}$ \\
\hline Spiny hackberry & $0.5^{\#}$ & $1.5^{\#}$ & 0.7 & 1.9 \\
\hline Texas persimmon & $0.3^{\#}$ & $1.4^{\#}$ & $0.4^{\#}$ & $2.0^{\#}$ \\
\hline Twisted acacia & $0.6^{* *}$ & $4.0^{* *}$ & $2.1^{\#}$ & $3.6^{\#}$ \\
\hline Whitebrush & 1.8 & 1.8 & 2.9 & 2.2 \\
\hline \multicolumn{5}{|l|}{ Succulent } \\
\hline Tasajillo & $<0.1^{\#}$ & $1.5^{\#}$ & $<0.1^{\#}$ & $2.0^{\#}$ \\
\hline Texas pricklypear & $0.2^{* *}$ & $3.1 * *$ & $0.1 * *$ & $3.1 * *$ \\
\hline \multicolumn{5}{|l|}{ Suffrutescent } \\
\hline Common lantana & 1.0 & 1.3 & 1.3 & 0.4 \\
\hline
\end{tabular}

sites 2 years post treatment may have resulted from tissue damage caused by the action of the aerator. Mechanical treatments such as root plowing and chaining can result in the retention and spread of intact cladophylls, thus increasing pricklypear density. Aeration appears to damage most cladophylls which may increase susceptibility of Texas pricklypear to disease and herbivory. Aeration was also highly effective in reducing tasajillo (Opuntia leptocaulis DC.) with little regeneration during the course of this study (Table 3, Table 4). The stress of drought before the aeration treatment may also have contributed to the decline of cacti on aerated sites.

Stem density of spiny hackberry and Texas persimmon (Diospyros texana Scheele) tended to increase during the first growing season following aeration; yet, increases did not persist into the second growing season post treatment (Table 4). Canopy cover of brasil was less on aerated sites throughout the study (Table 3), whereas stem density was similar between treatments (Table 4). Canopy cover and stem density of hog-plum, coma (Bumelia celastrina Kunth), guayacan (Guaiacum angustifolium Engelm.), and whitebrush [Aloysia gratissima (Gill. \& Hook.) Tron.] did not differ between treatments by the first growing season post treatment (Table 3, Table 4).

Spiny hackberry, brasil, and Texas persimmon are important forages for whitetailed deer and other wildlife (Everitt and Drawe 1993, Taylor et al. 1997) and their response following aeration may have resulted from herbivory by white-tailed deer and other herbivores. Top-removal of woody species can increase nutrient content of regrowth (Everitt 1983, Fulbright et al. 1991), which may increase utilization by herbivores (Rasmussen et al. 1983). Deer density on the study area during the duration of the study averaged 1 adult deer $23 \mathrm{ha}^{-1}$ year ${ }^{-1}$. However, adult deer densities increased from 1 adult deer $28 \mathrm{ha}^{-1}$ yea $^{-1}$ in 1999 to 1 adult deer 18 ha $^{-1}$ year $^{-1}$ in 2000, which may explain the observed declines in spiny hackberry and Texas persimmon stem density in 2000. Although herbivory may be an important factor influencing the response of woody plants to mechanical manipulation, it is unclear

Table 4. Mean density (stems $\mathrm{ha}^{-1}$ ) of dominant (frequency $>25 \%$ ) woody, succulent, and suffrutescent plants on aerated $(n=5)$ and nontreated $(n=5)$ sites, La Salle County, Tex. in 1999 and 2000.

\begin{tabular}{|c|c|c|c|c|}
\hline \multirow[b]{2}{*}{ Class/species } & \multicolumn{2}{|c|}{1999} & \multicolumn{2}{|c|}{2000} \\
\hline & Aerated & Nontreated & Aerated & Nontreated \\
\hline & \multicolumn{2}{|c|}{----(stems ha $\left.{ }^{-1}\right)----$} & \multicolumn{2}{|c|}{------(stems ha $\left.{ }^{-1}\right)-----$} \\
\hline \multicolumn{5}{|l|}{ Woody } \\
\hline Brasil & 196 & 140 & 149 & 135 \\
\hline Catclaw acacia & 151 & 251 & 160 & 350 \\
\hline Coma & 272 & 96 & 293 & 117 \\
\hline Guayacan & 128 & 169 & 197 & 108 \\
\hline Hog-plum & 901 & 356 & 729 & 204 \\
\hline Honey mesquite & 256 & 213 & $396^{\#}$ & $252^{\#}$ \\
\hline Spiny hackberry & $334^{\#}$ & $206^{\#}$ & 215 & 219 \\
\hline Texas persimmon & $124^{\#}$ & $59^{\#}$ & 89 & 119 \\
\hline Twisted acacia & 245 & 324 & 377 & 272 \\
\hline Whitebrush & 448 & 164 & 505 & 183 \\
\hline \multicolumn{5}{|l|}{ Succulent } \\
\hline Tasajillo & $5^{\#}$ & $441^{\#}$ & $20^{\#}$ & $485^{\#}$ \\
\hline Texas pricklypear & 1086 & 912 & $724^{\#}$ & $1090^{\#}$ \\
\hline \multicolumn{5}{|l|}{ Suffrutescent } \\
\hline Common lantana & 697 & 805 & 512 & 210 \\
\hline
\end{tabular}

For a given species, differences between treatments within any given year are indicated by: \# $\mathrm{P} \leq 0.1$. to what degree herbivores such as whitetailed deer, lagomorphs, rodents, and arthropods may have impacted regrowth of woody plants following aeration.

The response of spiny hackberry and guayacan to aeration was similar to other top-removal methods (Dodd 1968, Bozzo et al. 1992a). In contrast to this study, Bozzo et al. (1992a) reported that discing was effective in reducing whitebrush cover. While effective at removing the tops of woody plants, the toothed blades of the aerator may not cause significant damage to the regenerative burl of whitebrush.

Competition among woody plants may also explain reductions in some species. Declining species such as Texas pricklypear and tasajillo are closely associated with honey mesquite clusters (Whittaker et al. 1979, Archer et al. 1988), which can result in concentrations of woody plants relative to the interspace between clusters. Whitebrush, coma, and guayacan, which are also common components of shrub clusters (Stewart et al. 1997) and demonstrated little decline following aeration, appear to be more efficient in competing with other woody plants within clusters. Hog-plum and twisted acacia are most abundant in the interspace between honey mesquite-shrub clusters (Whittaker et al. 1979, Archer et al. 1988) where a lack of competition may explain their ability to rapidly produce top growth following aeration.

\section{Response of Herbaceous Plants}

Grass and forb richness, diversity, and evenness did not differ among treatments with the exception that grass species rich- 
Table 5. Mean grass and forb richness, diversity, and evenness on aerated $(n=5)$ and nontreated ( $n$ = 5) sites, La Salle County, Tex. in Spring and Fall 1999.

\begin{tabular}{cccc}
\hline \hline Class/season/treatment & Richness & Diversity & Evenness \\
\hline Grass & & & \\
Spring 1999 & 18 & 2.36 & 0.82 \\
$\quad$ Aerated & 17 & 2.31 & 0.81 \\
$\quad$ Nontreated & $2 *^{*}$ & 2.46 & 0.82 \\
Fall 1999 & $18^{*}$ & $2.27^{\#}$ & 0.79 \\
$\quad$ Aerated & & & \\
$\quad$ Nontreated & 41 & $2.97^{\#}$ & 0.80 \\
Forb $\quad 39$ & $2.83^{\#}$ & 0.77 \\
Spring 1999 & & & \\
$\quad$ Aerated & 27 & 2.29 & 0.71 \\
$\quad$ Nontreated & 26 & 2.29 & 0.71 \\
Fall 1999 & Aerated & & \\
$\quad$ Nontreated & & & \\
\hline
\end{tabular}

For a given index, differences between treatments within any given plant class and season are indicated by: ${ }^{*} \mathrm{P} \leq 0.05$, \# $\mathrm{P} \leq 0.1$. ness was greatest on aerated plots in fall 1999 (Table 5). Grass cover did not differ between treatments in spring 1999 and was greatest on aerated sites in fall 1999 (Table 6). Conversely, forb cover was greatest on aerated sites in spring 1999 and did not vary among treatments in fall 1999. Bare ground was greatest on nontreated sites and litter did not differ between treatments throughout the period of study. Total grass density did not differ $(P \geq 0.1)$ between aerated $\left(69.8\right.$ plants $\mathrm{m}^{-2}$, $64.7)$ and nontreated $(85.6,48.5)$ sites during spring and fall 1999, respectively. Total forb density was greater $(\mathrm{P}<0.001$, $\left.F_{1,8}=42.35\right)$ on nontreated $(118 \pm 4$ plants $\left.\mathrm{m}^{-2}\right)$ than aerated $(73 \pm 6)$ sites in spring 1999 and did not vary $(P=0.80$, $\mathrm{F}_{1,8}=0.07$ ) among aerated (24.7) and nontreated (26.8) sites in fall 1999. sites was similar to that observed by Box and Powell (1965) in which grass cover did not increase on roller chopped sites until 2 years after treatment. Competition among grasses and forbs may explain variations in grass cover and density among treatments. Cool-season annual forbs dominated all study plots during spring 1999. These ruderals are adapted to exploit areas subjected to soil disturbance, and their
The increase in grass cover on aerated overall increase in cover on aerated sites may have suppressed grasses. Natural absence of cool-season annual forbs coupled with above-average rainfall in late summer may have favored perennial grasses in fall 1999. Density of cattle feces was greater on aerated $(2,486 \pm 240 \mathrm{fecal}$ groups ha ${ }^{-1}, \mathrm{P}=0.0001, \mathrm{~F}_{1,8}=45.75$ ) than nontreated $(440 \pm 184)$ sites and may account for the observed increases in grass cover on aerated sites in fall 1999. Concentrations of cattle resulted in increased excreta loads, which in turn can increase the availability of nitrogen within upper soil layers and the root zone of many herbaceous species (Schuman et al. 1999). A reduced influence by important herbivores such as hispid cotton rat (Sigmodon hispidus Say and Ord) may also account for the increase in grasses on aerated sites. Hispid cotton rat diet is chiefly grass material (Randolph et al. 1991). Hispid cotton rat foraging behavior appears to be altered by aeration as abundance of hispid cotton rat was greater on nontreated than aerated sites (K. Krakauer, Unpublished data).

Aeration appears to be an effective tool to increase fringed signalgrass [Brachiaria ciliatissima (Buckl.) Chase], fall witchgrass [Digitaria cognata (Schult.) Pilger],
Table 6. Mean cover (\%) of grass, forb, litter, and bare ground on aerated $(n=5)$ and nontreated $(n=5)$ sites, La Salle County, Tex. in Spring and Fall 1999.

\begin{tabular}{ccccc}
\hline \hline & Grass & Forb & Litter & Bare Ground \\
\hline Spring 1999 & & & & \\
Aerated & $47^{\#}$ & $28^{* *}$ & 14 & $17^{*}$ \\
Nontreated & $40^{*}$ & $23^{* *}$ & 12 & $30^{*}$ \\
Fall 1999 & & & & \\
Aerated & $63^{* *}$ & $17^{\#}$ & 12 & $15^{* *}$ \\
Nontreated & $45^{* *}$ & $14^{\#}$ & 16 & $31^{* *}$ \\
\hline
\end{tabular}

For a given cover class, differences between treatments within any given season are indicated by: ${ }^{* *} \mathrm{P} \leq 0.01,{ }^{*} \mathrm{P} \leq$ 0.05 , \# $\mathrm{P} \leq 0.1$. and bristlegrass (Setaria spp. Beauv.) (Table 7), which provide fair to good grazing for livestock and wildlife (Gould 1978, Hatch and Pluhar 1993). Increases in bristlegrass after aeration were similar to that observed in blackbrush (Acacia rigidula Benth.) - guajillo (Acacia berlandieri Benth.) communities in South Texas (Ruthven et al. 2000b). Texas bristlegrass (Setaria texana (W. H. P. Emery) and [Setaria ramiseta (Scribn.) Pilger] were the 2 most common bristlegrasses encountered during this study, yet forage value of these species is unknown, and research into their importance as livestock and wildlife fodder in South Texas is needed. Purple threeawn (Aristida purpurea Nutt.), a grass of poor grazing value (Gould 1978, Hatch and Pluhar 1993), was effectively reduced by the aeration treatment (Table 7). Hairy grama is one of the more common native grasses on the study site, and although it produces relatively litthe top growth it is classified as a grass of fair value for livestock and wildlife (Gould 1978, Hatch and Pluhar 1993). Hairy grama has a poorly-developed root system and the decline of hairy grama on aerated sites in spring 1999 (Table 7) may have resulted from the uprooting and subsequent mortality of plants following the aeration treatment.

Lazy daisy (Aphanostephus spp. L.), an important forage for white-tailed deer (Everitt et al. 1999), typically increases following mechanical manipulation (Bozzo et al. 1992a, Fulbright 1999). In contrast, lazy daisy declined on aerated sites in this study with lower density $(\mathrm{P}=$ $0.01, \mathrm{~F} 1,8=10.13)$ on aerated $(4.4 \pm 1.4$ plants $\left.\mathrm{m}^{-2}\right)$ than nontreated $(21.2 \pm 5.2)$ sites. Declines of lazy daisy may be explained by herbivory. Mechanical brush control can increase preference for woody plants by white-tailed deer (Powell and Box 1966) and increase utilization of treated areas (Bozzo et al. 1992b). It is unclear to what degree herbivory by white-tailed deer and other herbivores may have impacted forbs on aerated sites.

\section{Conclusions and Management Implications}

Declines in cacti, increases in stem density of desirable woody plants, and increases in grass cover following aeration suggest it may be a useful tool in managing South Texas rangelands for both white-tailed deer and cattle. Aeration also appears to maintain woody plant diversity, which can decline with many traditional 
Table 7. Mean cover $(\%)$ and density (plants $\mathrm{m}^{-2}$ ) of dominant (frequency $>25 \%$ ) grasses on aerated $(\mathrm{n}=\mathbf{5})$ and nontreated $(\mathrm{n}=\mathbf{5})$ sites, La Salle County, Tex. in Spring and Fall 1999.

\begin{tabular}{|c|c|c|c|c|c|c|c|c|}
\hline \multirow[b]{3}{*}{ Species } & \multicolumn{4}{|c|}{ Cover } & \multicolumn{4}{|c|}{ Density } \\
\hline & \multicolumn{2}{|c|}{ Spring } & \multicolumn{2}{|c|}{$\underline{\text { Fall }}$} & \multicolumn{2}{|c|}{ Spring } & \multicolumn{2}{|c|}{ Fall } \\
\hline & Aerated & Nontreated & Aerated & Nontreated & Aerated & Nontreated & Aerated & Nontreated \\
\hline & & $-(\%$ & & -- & & ---(plar & $2) \ldots$ & $\cdots$ \\
\hline Bristlegrass & $4.5^{* *}$ & $1.6^{* *}$ & $6.9^{* *}$ & $2.2 * *$ & $3.9^{*}$ & $1.7 *$ & $3.9 * *$ & $1.3^{* *}$ \\
\hline Fall witchgrass & $9.3^{*}$ & $5.0^{*}$ & $14.2 *$ & $6.5^{*}$ & 9.2 & 7.6 & $9.8^{*}$ & 5.3 \\
\hline Fringed signalgrass & $7.8^{\#}$ & $5.3^{\#}$ & $6.7^{*}$ & $3.1^{\text {* }}$ & 12.5 & 12.9 & 7.6 & 5.1 \\
\hline Hairy grama & $1.3^{*}$ & $3.1 *$ & 7.9 & 7.6 & $3.8^{*}$ & $11.0 *$ & 9.2 & 11.9 \\
\hline Lehmann lovegrass & 7.2 & 6.5 & 8.1 & 4.7 & 10.0 & 15.5 & 4.3 & 4.3 \\
\hline Purple threeawn & $2.0^{* *}$ & $5.4 * *$ & $1.2^{* *}$ & $7.0^{* *}$ & 2.6 & 4.9 & $1.0 * *$ & $3.6^{* *}$ \\
\hline Red lovegrass & 1.3 & 1.9 & 3.0 & 2.6 & 2.8 & $6.2^{\#}$ & $3.7^{\#}$ & 3.3 \\
\hline Thin paspalum & 8.2 & 7.2 & 6.6 & 5.2 & 9.3 & 10.0 & 6.8 & 6.4 \\
\hline
\end{tabular}

For a given species, differences between treatments within any given season are indicated by: ** $\mathrm{P} \leq 0.01, * \mathrm{P} \leq 0.05, \# \mathrm{P} \leq 0.1$

mechanical treatments (Fulbright and Beasom 1987, Ruthven et al. 1993). Expected treatment life of mechanical topremoval methods such as aeration is relatively short at 2-3 years (Welch et al. 1985). Short treatment life necessitates the need for the application of maintenance treatments to extend treatment benefits. Where feasible, application of prescribed fire is recommended to extend the life of mechanically treated rangelands (Welch et al. 1985, Scifres and Hamilton 1993). Increases in grass cover can facilitate the successful use of fire and similar aerated sites on the study area were successfully burned approximately 18 months following treatment (Rogers 2002).

If managing South Texas rangelands for white-tailed deer is a primary management goal, it may be beneficial to target areas dominated by preferred browse species such as spiny hackberry and Texas persimmon which rapidly sprout following aeration and limit the use of aeration on sites dominated by less desirable species such as whitebrush and twisted acacia which also quickly produce top growth following aeration. Although canopy cover of less desirable browse species such as honey mesquite decline following aeration, the importance of these species to other game and nongame wildlife is not well documented. The effects of the structural changes of woody plant communities following mechanical treatment such as

Appendix Table 1. Scientific and common names of woody, succulent, suffrutescent, and herbaceous species.

\begin{tabular}{|c|c|c|}
\hline & Scientific name ${ }^{1}$ & Common Name \\
\hline Woody plants & Acacia greggii Gray & Catclaw acacia \\
\hline Suffrutescents & Lantana horrida Kunth & Common lantana \\
\hline Grasses & $\begin{array}{l}\text { Eragrostis secundiflora Presl } \\
\text { Paspalum setaceum Michx. }\end{array}$ & $\begin{array}{l}\text { Red lovegrass } \\
\text { Thin paspalum }\end{array}$ \\
\hline
\end{tabular}

${ }^{1}$ Hatch et al. (1990) aeration on nongame wildlife warrant further investigation.

An increase in forbs is a desired effect of mechanical treatments, yet response of herbaceous vegetation to mechanical brush management treatments may depend on precipitation (Waid et al. 1984, Rollins and Bryant 1986, Bozzo et al. 1992a). Weather patterns in South Texas are highly unpredictable with highly variable rainfall amounts between locations and frequent periods of short-term drought (Norwine and Bingham 1985). Average rainfall pattern in South Texas is bimodal with peaks in late spring and early fall (Stevens and Arriaga 1985) and timing of mechanical treatments prior to these time periods may increase the probability of a positive response by herbaceous vegetation.

There are few data on the direct effects of mechanical treatments such as aeration on wildlife and timing of treatment may adversely impact certain wildlife populations. Most herpetofauna hibernate during the winter months. In South Texas, the Texas horned lizard (Phrynosoma cornutum Gray), a state Threatened Species, hibernates at shallow depths (Fair and Henke 1997; Unpublished data, D. Ruthven). Mortality may result if mechanical treatment is applied during the dormant period. Aeration conducted during summer, when herpetofauna are active, may lessen the probability of direct mortality.

Herbivory, climatic, edaphic, and temporal factors may influence the response of vegetation to mechanical treatments. Productivity of herbaceous plant communities decrease along the decreasing east to west precipitation gradient across South Texas, which may increase the utilization of woody plants by herbivores. Response of vegetation to top-removal methods can vary by treatment date within a climatic season and among soil types (Hansmire et al. 1988). Further study into the effects of herbivory, season of treatment application, influence of pre- and post-treatment climatic variables, and direct and indirect impacts of mechanical treatments on wildlife are needed to fully assess the effects of aeration and its use as a management tool on semiarid rangelands.

\section{Literature Cited}

Allison, D.V. and C.A. Rechenthin. 1956. Root plowing proved best method of brush control in South Texas. J. Range Manage. 9:130-133.

Archer, S. 1994. Woody plant encroachment into southwestern grasslands and savannas: rates, patterns and proximate causes, $p$ 13-68. In: M. Vavra et al. (eds.) Ecological implications of livestock herbivory in the west. Society for Range Management, Denver, Colo.

Archer, S., C. Scifres, C.R. Bassham, and R. Maggio. 1988. Autogenic succession in a subtropical savanna: conversion of grassland to thorn woodland. Ecol. Monogr. 58:111-127.

Arnold, L.A. and D.L. Drawe. 1979. Seasonal food habits of white-tailed deer in the south Texas plains. J. Range Manage. 32:175-178.

Box, T.W. and J. Powell. 1965. Brush management for improved forage values in south Texas. Trans. North Amer. Wildl. Conf. 30:285-296.

Bozzo, J.A., S.L. Beasom, and T.E. Fulbright. 1992a. Vegetation responses to 2 brush management practices in South Texas. J. Range Manage. 45:170-175. 
Bozzo, J.A., S.L. Beasom, and T.E. Fulbright. 1992b. White-tailed deer use of rangeland following browse rejuvenation. J. Range Manage. 45:496-499.

Bunting, S.C., H.A. Wright, and L.F. Neuenschwander. 1980. Long-term effects of fire on cactus in the southern mixed prairie of Texas. J. Range Manage. 33:85-88.

Burrow, A.L, R.T. Kazmaier, E.C. Hellgren, and D.C. Ruthven, III. 2001. Microhabitat selection by Texas horned lizards in southern Texas. J. Wildl. Manage. 65:645-652.

Canfield, R.H. 1941. Application of line interception in sampling range vegetation. J. Forest. 39:388-394.

Daubenmire, R.F. 1959. A canopy coverage method of vegetation analysis. Northwest Sci. 33:43-64.

Dodd, J.D. 1968. Mechanical control of pricklypear and other woody species on the Rio Grande Plains. J. Range Manage. 21:366-370

Everitt, J.H. 1983. Effects of plant shredding on nutrient content of four south Texas deer browse species. J. Range Manage. 36:779-781.

Everitt, J.H. and D.L. Drawe. 1993. Trees, shrubs and cacti of South Texas. Texas Tech University Press, Lubbock, Tex.

Everitt, J.H., D.L. Drawe, and R.I. Lonard. 1999. Field guide to the broad-leaved herbaceous plants of South Texas used by livestock and wildlife. Texas Tech University Press, Lubbock, Tex.

Fair, W.S. and S.E. Henke. 1997. Effects of habitat manipulations on Texas horned lizards and their prey. J. Wildl. Manage. 61:1366-1370.

Fulbright, T.E. 1999. Response of white-tailed deer foods to discing in a semiarid habitat. J. Range Manage. 52:346-350.

Fulbright, T.E. and S.L. Beasom. 1987. Long-term effects of mechanical treatments on white-tailed deer browse. Wildl. Soc. Bull. 15:560-564.

Fulbright, T.E., J.P. Reynolds, S.L. Beasom, and S. Demarais. 1991. Mineral content of guajillo regrowth following roller chopping. J. Range Manage. 44:520-522.

Gabor, T. 1997. Ecology and interactions of sympatric collared peccaries and feral pigs. Ph.D. Diss., Oklahoma State Univ., Stillwater, Okla.

Gabriel, W.J., D. Arriaga, and J.W. Stevens. 1994. Soil survey of LaSalle County, Texas. USDA, Washington, D.C.

Gould, F.W. 1978. Common Texas grasses: an illustrated guide. Texas A\&M University Press, College Station, Tex.

Guthery, F.S. 1986. Beef, brush and bobwhites: quail management in cattle country. Golden Banner Press, Inc., Corpus Christi, Tex.

Hansmire, J.A., D.L. Drawe, D.B. Wester, and C.M. Britton. 1988. Effects of winter burns on forbs and grasses of the Texas Coastal Prairie. Southwest. Nat. 33:333-338.

Hatch, S.L. and J. Pluhar. 1993. Texas Range Plants. Texas A\&M University Press, College Station, Tex.
Hatch, S.L., K.N. Gandhi, and L.E. Brown. 1990. Check list of the vascular plants of Texas. Tex. Agr. Exp. Sta. Misc. Pub. MP1655 , College Station, Tex.

Kazmaier, R.T. 2000. The effects of grazing on ecology and demography of the Texas tortoise (Gopherus berlandieri) in the western Rio Grande Plains. Ph.D. Diss., Oklahoma State Univ., Stillwater, Okla.

Lehmann, V.W. 1969. Forgotten legions: sheep in the Rio Grande Plain of Texas. Texas Western Press, El Paso, Tex.

McLendon, T. 1991. Preliminary description of the vegetation of south Texas exclusive of coastal saline zones. Tex. J. Sci. 43:13-32.

Montemayor, E., T.E. Fulbright, L.W. Brothers, B.J. Schat, and D. Cassels. 1991. Long-term effects of rangeland disking on white-tailed deer browse in south Texas. J. Range Manage. 44:246-248.

Norwine, J. and R. Bingham. 1985. Frequency and severity of drought in south Texas, p. 1-19. In: R. Brown (ed) Livestock and wildlife management during drought. Caesar Kleberg Wildl. Res. Inst., Kingsville, Tex.

Nudds, T.R. 1977. Quantifying the vegetative structure of wildlife cover. Wildl. Soc. Bull. 5:113-117.

Pielou, E.C. 1975. Ecological diversity. John Wiley \& Sons, New York, N.Y.

Powell, J. and T.W. Box. 1966. Brush management influences preference values of south Texas woody species for deer and cattle. J. Range Manage. 19:212-214.

Randolph, J.C., G.N. Cameron, and J.A. Wrazen. 1991. Dietary choice of a generalist grassland herbivore, Sigmodon hispidus. J. Mamm. 72:300-313.

Rasmussen, G.A., C.J. Scifres, and D.L. Drawe. 1983. Huisache growth, browse quality, and use following burning. J. Range Manage. 36:337-342.

Reynolds, J.F., R.A. Virginia, P.R. Kemp, A.G. de Soyza, and D.C. Tremmel. 1999. Impact of drought on desert shrubs: effects of seasonality and degree of resource island development. Ecol. Monogr. 69:69-106.

Rogers, J.O. 2002. Vegetation regrowth and deer utilization of aerated plots after maintenance burning and re-aeration. M. S. Thesis, Texas A\&M University-Kingsville, Kingsville, Tex.

Rollins, D. and F.C. Bryant. 1986. Floral changes following mechanical brush removal in central Texas. J. Range Manage. 39:237-240.

Ruthven, D.C., III, J.F. Gallagher, and D.R. Synatzske. 2000a. Effect of fire and grazing on forbs in the western south Texas plains. Southwest. Nat. 445:89-94.

Ruthven, D.C., III, D.R. Rios, and A.G. Gandaria. 2000b. Response of herbaceous vegetation to aeration of a blackbrush-guajillo community. Tex. J. Agr. Nat. Resour. 13:51-60.

Ruthven, D.C., III, T.E. Fulbright, S.L. Beasom, and E.C. Hellgren. 1993. Longterm effects of root plowing on vegetation in the eastern south Texas plains. J. Range Manage. 46:35l-354.
Schuman, G.E., J.D. Reeder, J.T. Manley, R.H. Hart, and W.A. Manley. 1999. Impact of grazing management on the carbon and nitrogen balance of a mixed-grass rangeland. Ecol. Appl. 9:65-71.

Scifres, C.J. and W.T. Hamilton. 1993. Prescribed burning for brushland management: the south Texas example. Texas A\&M University Press, College Station, Tex.

Scifres, C.J., J.L. Mutz, and G.P. Durham. 1976. Range improvement following chaining of south Texas mixed brush. J. Range Manage. 29:418-421.

Sowls, L.K. 1997. Javelinas and other peccaries: their biology, management, and use. Texas A\&M University Press, College Station, Tex.

Stevens, J.W. and D. Arriaga. 1985. Soil survey of Dimmit and Zavala Counties, Texas. USDA, Washington, D.C.

Stewart, K.M., J.P. Bonner, G.R. Palmer, S.F. Patten, and T.E. Fulbright. 1997. Shrub species richness beneath honey mesquite on root-plowed rangeland. J. Range Manage. 50:213-216.

Taylor, R.B., J. Rutledge, and J.G. Herrera. 1997. A field guide to common south Texas shrubs. Texas Parks and Wildlife Press. Austin, Tex.

Waid, D.D., R.J. Warren, and D. Rollins. 1984. Seasonal deer diets in central Texas and their response to brush control Southwest. Nat. 29:301-307.

Welch, T.G., R.P. Smith, and G.A. Rasmussen. 1985. Brush management technologies, p. 15-24. In: Integrated brush management systems for south Texas: Development and implementations. Tex. Agr. Exp. Sta., Texas A\&M Univ., College Station, Tex.

Whittaker, R.H., L.E. Gilbert, and J.H. Connell. 1979. Analysis of two-phase pattern in a mesquite grassland, Texas. J. Ecol. 67:935-952.

Wilkins, N., R.D. Brown, R.J. Conner, J. Engle, C. Gilliland, A. Hays, R.D. Slack, and D.W. Steinbach. 2000. Fragmented lands: changing land ownership in Texas. Texas A\&M Univ, Agr. Commun. Pub. MKT-3443, College Station, Tex. 